\title{
Ferulago pauciradiata Boiss. \& Heldr. Effects of Prantschimgin Compound Isolated from the Root of the Plant on LPS-Induced Inflammation Model in the L929 Cell Line
}

\author{
Zerrin KUTLU ${ }^{1 *}$ (D), Sevgi KARABULUT UZUNCAKMAK²(D, Songul KARAKAYA ${ }^{3}$, \\ Fatmagul DELIMUSTAFAOGLU ${ }^{4}$ \\ ${ }^{1}$ Department of Biochemistry, Faculty of Pharmacy, Atatürk University, Erzurum 25240,Turkey \\ ${ }^{2}$ Health Services Vocational School, Bayburt University, Bayburt, 69000, Turkey \\ ${ }^{3}$ Department of Pharmacognosy, Faculty of Pharmacy, Ataturk University, Erzurum,25240, Turkey \\ ${ }^{4}$ Department of Pharmaceutical Botany, Faculty of Pharmacy, Ankara University,Ankara, 06000, Turkey
}

Geliş / Received: 18/08/2020, Kabul / Accepted: 22/04/2021

\begin{abstract}
Investigation of the effects of prantchimgin (Prn) compound isolated from the root part of the Ferulago pauciradiata (Apiaceae) plant in the lipopolysaccharide (LPS) cytotoxicity model created in the L929 cell line. $\mathrm{L} 929$ cell lines were applied in a $5 \% \mathrm{CO}_{2}$ incubator at $37^{\circ} \mathrm{C}$, using standard cell culture procedures, LPS was applied with Prn pure substance with a final concentration of $2 \mu \mathrm{L}$ and $1 \mu \mathrm{L}$ after 1 hour. Following the LPS application, the MTT protocol, a colorimetric method, was applied to determine cell viability at the end of the required 24th, 48th, and 72nd hours incubation times. $\mathrm{IC}_{50}$ values were calculated as $0.28 \mu \mathrm{g} / \mathrm{mL}$ for Pnr and $1 \mu \mathrm{g} / \mathrm{mL}$ for LPS. Application of LPS to L929 cell lines caused a significant decrease in cellular index depending on time. Also, in the Prn + LPS groups, it was found that the decreased cell index significantly increased even closer to the control compared to the LPS applied group. It was found that cyctoxicity and cell damage caused by LPS applied to the L929 cell line improved after Pnr application.
\end{abstract}

Keywords: Ferulago pauciradiata, cyctoxicity, L929, LPS, MTT, prantschimgin

\section{L929 Hücre Hattında Lipopolisakkaritle İndüklenen Sitotoksisite Modeli Üzerine Ferulago pauciradiata Boiss. \& Heldr. Bitkisinin Kökünden İzole Edilen Prantşimgin Bileşiğinin Etkisinin İncelenmesi}

\section{$\ddot{O} z$}

L929 hücre hattında oluşturulan lipopolisakkarit (LPS) kaynaklı sitotoksisite modelinde Ferulago pauciradiata (Apiaceae) bitkisinin kök kısmından izole edilen prantşimgin (Prn) bileşiğinin etkisinin incelenmesi. L929 hücre hatlar1, $37^{\circ} \mathrm{C}$ 'de $\% 5 \quad \mathrm{CO}_{2}$ 'li inkübatörde standart hücre kültürü prosedürleri kullanılarak son konsantrasyonu $2 \mu \mathrm{L}$ olacak şekilde Prn saf maddesi ve 1 saat sonra son konsantrasyonu $1 \mu \mathrm{L}$ olacak şekilde LPS uygulandı. LPS uygulamasının ardından, gerekli olan 24, 48 ve 72 saat inkübasyon süreleri sonunda sitotoksik etkilerin belirlenmesi amaciyla kolorimetrik bir metot olan MTT protokolü uyguland1. IC $_{50}$ değerleri, Prn için $0.28 \mu \mathrm{g} / \mathrm{mL}$ ve LPS için ise $1 \mu \mathrm{g} / \mathrm{mL}$ olarak hesapland1. L929 hücre hatlarına LPS uygulanmasının zamana bağlı olarak hücresel indekste anlamlı derecede azalmaya neden olmuştur. Ayrıca Prn+LPS gruplarında ise sadece LPS uygulanan grubuna göre azalmış hücre indeksini, anlamlı derecede artırdığ 1 hatta kontrole yaklaştırdığı tespit edilmiştir.L929 hücre hattına uygulana LPS ile oluşturulan sitotoksisite ve hücre hasarını Pnr uygulaması sonucunda düzeldiği tespit edildi.

\footnotetext{
*Corresponding Author: kutluzerrin@ atauni.edu.tr
} 
Anahtar kelimeler: Apiaceae, Ferulago pauciradiata, sitotoksisite, L929, LPS, MTT, prantşimgin

\section{Introduction}

Our country has a very wide flora in terms of plant diversity. Many of the drugs used today are directly or indirectly obtained from plants. (Tokur and Aksoy, 2017) Some plants have various activities due to the compounds such as coumarins, phenolic compounds and flavonoids they contain. Because of these properties of plants, researchers have recently preferred plants as therapeutic agents.(Zhang et al., 2017; Kutlu et al., 2020)

Medicinal plants used for various reasons since ancient times have made many contributions to human health. (Sheba ve Anuradha, 2019) Ferulago pauciradiata Boiss. \& Heldr. (Apiaceae) is a perennial species. Ferulago species are used in folk medicine in ulcers and dermatological diseases. (Karakaya et al., 2018). Studies have found that coumarins have many pharmacological properties such as antibacterial, anticoagulant, antipyretic, vasodilator, and anticarcinogen (Srikrishna et al., 2018). Fibroblasts are a type of cell found in all tissues of the body (Thomas 2019). In the normal process, fibroblasts act as sentinel-like cells in the tissue and are the first to respond to damage signals (Millar et al., 2012).

The lipopolysaccharide (LPS) induced cytotoxicity model, which is a component of the cell wall of Gram-negative bacteria, is the most preferred model in in vitro cytotoxicity studies. We aim to investigate the effects of the prantchimgin (Prn) compound isolated from the root part of the Ferulago pauciradiata (Apiaceae) plant in the lipopolysaccharide (LPS) induced cytotoxicity model created in the L929 cell line.

\section{Materials and Methods}

\subsection{Materials}

\subsubsection{Plant Material}

Ferulago pauciradiata specimens were collected in Nevşehir in 2013 and identified by XXXX (Department XXXX). The voucher specimens were kept at the herbarium of Ankara University, Faculty of Pharmacy, with the number of AEF 26360.

\subsubsection{Cell Lines}

In this study, the L929 cell line was used to evaluate the effects of Prn compound isolated from the root part of Ferulago pauciradiata on LPS-induced cell damage in the L929 (ATCC® CRL-2091) cell line. The L929 cell line was purchased from the American Type Culture Collection (ATCC, USA) and used by reproducing from existing stocks available in the Cell Culture Laboratory, affiliated to the Department of Medical Pharmacology, Atatürk University School of Medicine. 


\subsection{Methods}

\subsubsection{Extraction and Isolation}

Prantchimgin was obtained using the method described by Karakaya et al. (Karakaya et al. 2017 and Karakaya et al. 2018). 125 g dried crushed plant material was utilized and known compound prantchimgin was obtained. Ferulago pauciradiata specimens were collected in Nevşehir in 2013 and identified by Prof. Dr. Hayri DUMAN. The voucher specimens were kept at the herbarium of Ankara University, Faculty of Pharmacy, with the number of AEF 26360 .

\subsubsection{Experimental Protocol and Details}

This study was carried out in the Cell Culture Laboratory of the Department of Medical Pharmacology, Faculty of Medicine, Atatürk University. First, different concentrations of doses were determined to calculate the $\mathrm{IC}_{50}$ value of the Prn compound and LPS (Table 1).

Table 1. Doses used to calculate $\mathrm{IC}_{50}$ values of LPS and Prn

\begin{tabular}{ccc}
\hline \multicolumn{3}{c}{ Concentartions } \\
\hline \hline LPS & & Prn \\
\hline \hline $20 \mu \mathrm{g} / \mathrm{mL}$ & $8 \mu \mathrm{g} / \mathrm{mL}$ \\
$15 \mu \mathrm{g} / \mathrm{mL}$ & $4 \mu \mathrm{g} / \mathrm{mL}$ \\
$10 \mu \mathrm{g} / \mathrm{mL}$ & $2 \mu \mathrm{g} / \mathrm{mL}$ \\
$7.5 \mu \mathrm{g} / \mathrm{mL}$ & $1 \mu \mathrm{g} / \mathrm{mL}$ \\
$5 \mu \mathrm{g} / \mathrm{mL}$ & $0.5 \mu \mathrm{g} / \mathrm{mL}$ \\
$2.5 \mu \mathrm{g} / \mathrm{mL}$ & \\
$1 \mu \mathrm{g} / \mathrm{mL}$ & \\
\hline
\end{tabular}

LPS; lipopolysaccharide, Prn; prantchimgin

After the cells preserved in Cryotube in the liquid nitrogen tank were dissolved, they were planted in flasks of $T 75 \mathrm{~cm}^{2}$ (Gibco®, UK) with filtered cap. After the cells were determined with the help of Inverted (Leica ${ }^{\circledR}$, Germany) light microscope (20X-40X), where $85-90 \%$ of them became confluent (20X-40X), $5 \times 10^{3}$ cells were sown in each well of 96-well microplates. After that, Prn and LPS applications were performed and a colorimetric method (3- [4,5- dimethylthiazol-2-yl] -2,5-diphenyl tetrazolium bromide (MTT) protocol was applied to determine cytotoxic effects.

\subsubsection{Preparation of Prantchimgin and LPS}

Since the Prn compound is insoluble in water, $1 \%$ dimethyl sulfoxide was added to dissolve the substance after vortexing. Different concentrations $(8 \mu \mathrm{g} / \mathrm{mL} ; 4 \mu \mathrm{g} / \mathrm{mL} ; 2 \mu \mathrm{g} / \mathrm{mL} ; 1 \mu \mathrm{g}$ $/ \mathrm{mL} ; 0.5 \mu \mathrm{g} / \mathrm{mL}$ ) after passing through the sterile filter (Catalog no: 1520012, GyroDisc CA-PA) with sol pore diameter of $0.2 \mu \mathrm{m}$ It was prepared. LPS (E. Coli O55: B5, SigmaAldrich ${ }^{\circledR}$, St. Louis, USA) in lyophilized form was dissolved in pure water to prepare different concentrations. 


\subsubsection{Cell Culture Studies}

Different cell lines grow in different environments. The L929 cell line is 89\% DMEM (Gibco®, New York, USA), 10\% FBS (Gibco®, New York, USA), 1\% PSA (Gibco®, New York, USA) and 2\% L-Glutamine (It is grown in medium containing CAS No: 56-85-9, Sigma-Aldrich ${ }^{\circledR}$, St. Louis, USA). Cells were proliferated using standard cell culture procedures in a $5 \% \mathrm{CO}_{2}$ incubator $\left(\mathrm{NuAire} \AA\right.$, America) at $37{ }^{\circ} \mathrm{C}$. With the help of the Inverted light microscope (Leica ${ }^{\circledR}$, Germany), after determining that the cells are in a confluent state with $85-90 \%$ density, after mixing $100 \mu \mathrm{L}$ trypan blue, $90 \mu \mathrm{L}$ PBS, $10 \mu \mathrm{L}$ medial cell in the micro eppendorf tube, $10 \mu \mathrm{L}$ of this mixture was taken to determine the number of live cells in the cell counting device (INNOVATIS ${ }^{2}$, Virginia). After making the necessary calculations, sowing was performed with $5 \times 10^{3}$ cells (number of groups $\times 5 \times 10^{3}$ ) in each well.

\subsubsection{Evaluation of Cell Viability with the MTT Method}

L929 cell lines cultivated in three microplates (for 24th, 48th, and 72nd hours) with $5 \times 10^{3}$ cells (ie 5000 cells at $150 \mu \mathrm{L}$ ), the standard cell in a $5 \% \mathrm{CO}_{2}$ incubator at $37{ }^{\circ} \mathrm{C}$. The cells were allowed to incubate for 24th hours using culture procedures. At the end of the incubation period, the Prn compound was applied with a final concentration of $2 \mu \mathrm{L}$ at the doses determined first and LPS was applied after 1 hour with a final concentration of $1 \mu \mathrm{L}$. Following the LPS application, a colorimetric method MTT (Cat. No. 11465007 001, Roche) protocol was applied to determine cytotoxic effects at the end of the required 24th, 48th, and 72nd hours incubation times. The $\%$ viable cell ratio was calculated using the following equation.

$\%$ Percentage viability $=\frac{(\text { Compound }- \text { treated cell absorbance })-(\text { absorbance of the empty well })}{\text { (control cell absorbance }- \text { absorbance of the empty well) }} \times 100$

\section{Statistical Analysis}

The data were evaluated statistically using IBM 22.00 SPSS software. To test the compliance of the data with a normal distribution (Gaussian), a Shapiro-Wilk W-test was applied to each group. Data with a p-value greater than 0.05 was considered to be normally distributed, and a skewness test was used to test its normal distribution. Levene's test was used to test the homogeneity of the variances. The variance of data with a p-value greater than 0.05 was considered homogeneous. The statistical analysis data that did not exhibit homogeneous variance was conducted using a Games-Howell test, which involved a one-way ANOVA and post-hoc multiple comparison tests; $\mathrm{p}<0.05$ was considered significant. The statistical analysis of data that did not exhibit homogeneous variance were conducted using a Tukey and Duncan tests, which consisted of a one-way ANOVA and post-hoc multiple comparative tests. 


\section{Resarch Findings}

\subsection{LPS and $\mathrm{IC}_{50}$ Values of Prantchimgin}

To determine the most effective dose on the L929 cell line, Prn pure substance and LPS obtained from the root part of Ferulago pauciradiata at different concentrations were applied. $\mathrm{IC}_{50}$ values that inhibit the proliferation of $50 \%$ of different concentrations of Prn and LPS on the L929 cell line in vitro were determined (Table 1).

$\mathrm{IC}_{50}$ values were calculated as $0.28 \mu \mathrm{g} / \mathrm{mL}$ for Prn (Figure 1) and $\mathrm{IC}_{50}$ for LPS (Figure 2) as 1 $\mu \mathrm{g} / \mathrm{mL}$ using the logarithmic transformation of Prn and LPS concentration and nonlinear regression sigmoidal dose-response analysis (GraphPad 8.0 Prism, La Jolla, CA).

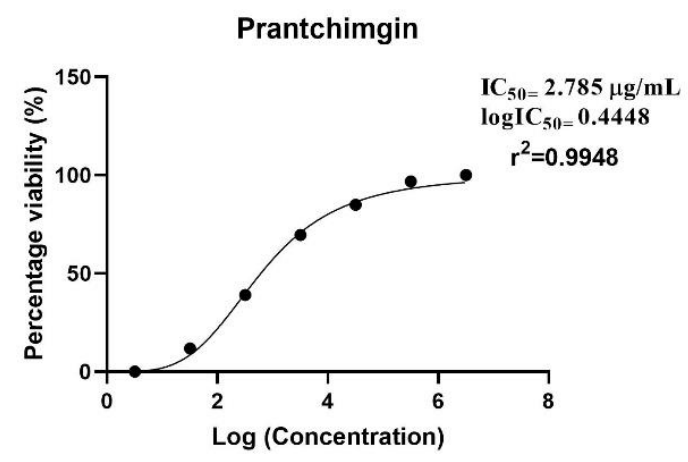

Figure 1. $\mathrm{IC}_{50}$ value of prantchimgin

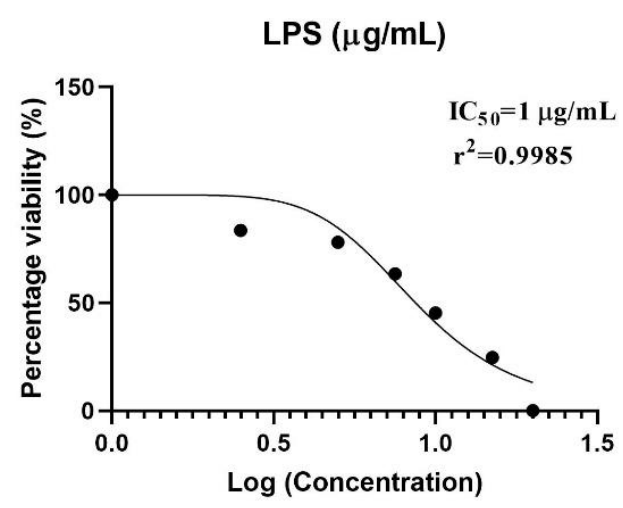

Figure 2. $\mathrm{IC}_{50}$ value of LPS

\subsection{Results of Cell Viability}

The cell viability of the control group was considered as 100\%. After applying LPS to the L929 cell line, when we compared the live-cell ratio in the LPS group with the live-cell ratio of the control group, a statistically significant difference was found $(\mathrm{p}<0.0001)$. When LPS is applied 1 hour after applying different doses of Prn pure substance $(8 \mu \mathrm{g} / \mathrm{mL} ; 4 \mu \mathrm{g} / \mathrm{mL} ; 2$ $\mu \mathrm{g} / \mathrm{mL} ; 1 \mu \mathrm{g} / \mathrm{mL} ; 0.5 \mu \mathrm{g} / \mathrm{mL}$ ) obtained from the root part of the Ferulago pauciradiata, the concentration of Prn pure substance increases It was determined that it increased cell proliferation and the highest live cell ratio was observed at a dose of $8 \mu \mathrm{g} / \mathrm{mL}$ (Figure 3). 
According to the MTT protocol, the proportion of viable cells in the LPS group was $64.39 \%$ at 24th hours. When the proliferative effect of Prn pure substance on L929 cells was compared with the control group, it was determined that there were $91.78 \%$ live cells, and in the group that received Prn + LPS, 85.12\% were live cells (Figure 4).

\section{MTT}

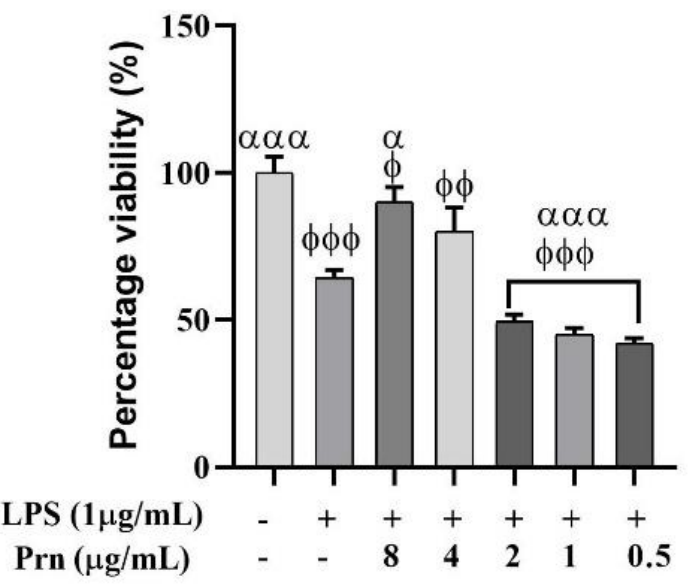

Figure 3. The effect of LPS and Prn agents applied on the L929 cell line on cell viability. ( $\Phi$; according to control group, ${ }^{\Phi} \mathrm{p}<0.05,{ }^{\Phi}{ }^{\Phi} \mathrm{p}<0.01,{ }^{\Phi} \Phi \mathrm{p}<0.001 ; \alpha$ :according to LPS group $\alpha$ $\left.\mathrm{p}<0.05,{ }^{\alpha \alpha} \mathrm{p}<0.01,{ }^{\alpha \alpha \alpha} \mathrm{p}<0.001\right)$

24th hour

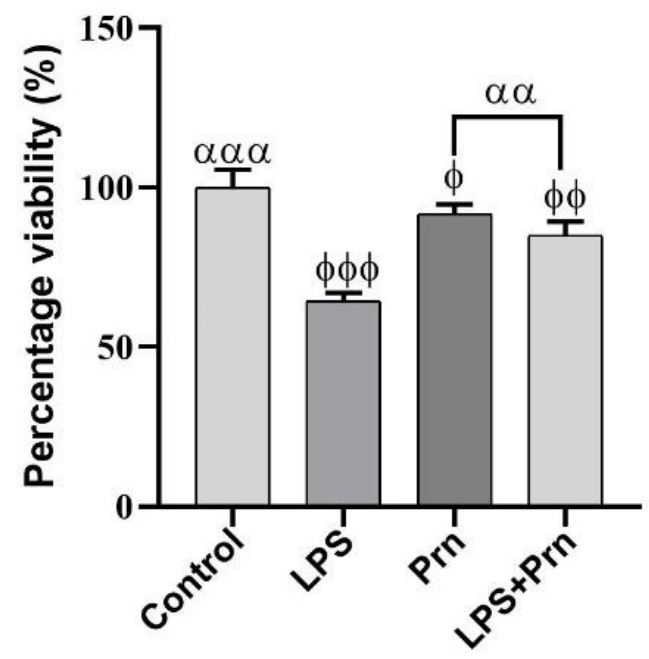

Figure 4. The effects of Prn and LPS on L929 cell line in 24th hours. ( $\Phi$; according to control group, ${ }^{\Phi} \mathrm{p}<0.05,{ }^{\Phi \Phi} \mathrm{p}<0.01,{ }^{\Phi \Phi} \mathrm{p}<0.001 ; \alpha$ :according to LPS group ${ }^{\alpha} \mathrm{p}<0.05,{ }^{\alpha}{ }^{\alpha} \mathrm{p}<0.01,{ }^{\alpha \alpha \alpha} \mathrm{p}<0.001$ )

The live-cell ratio was 48.4\% 48th hours after the Prn compound was applied on the L929 cell line. 48th hours after the LPS application, the live cell ratio in the LPS group was $38.79 \%$ and $87.33 \%$ in the Prn + LPS group (Figure 5). 


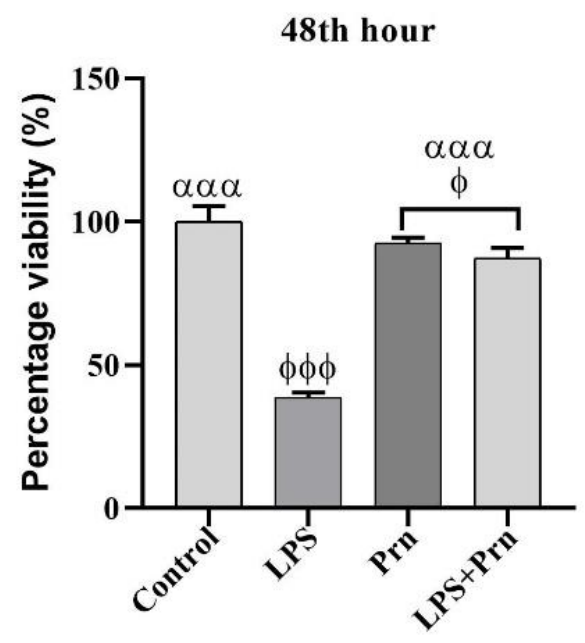

Figure 5. The effects of Prn and LPS on L929 cell line in 48th hours. ( $\Phi$; according to control group, ${ }^{\Phi} \mathrm{p}<0.05,{ }^{\Phi \Phi} \mathrm{p}<0.01,{ }^{\Phi \Phi} \mathrm{p}<0.001 ; \alpha$ :according to LPS group ${ }^{\alpha} \mathrm{p}<0.05,{ }^{\alpha}{ }^{\alpha} \mathrm{p}<0.01,{ }^{\alpha \alpha \alpha} \mathrm{p}<0.001$ )

When we look at the effects of the Prn compound on L929 cells after 72nd hours, the live cell ratio was found to be $93.78 \%$ in the Prn group and $89.18 \%$ in the group receiving Prn + LPS. In the LPS group, it was determined that $19.92 \%$ live cells (Figure 6).

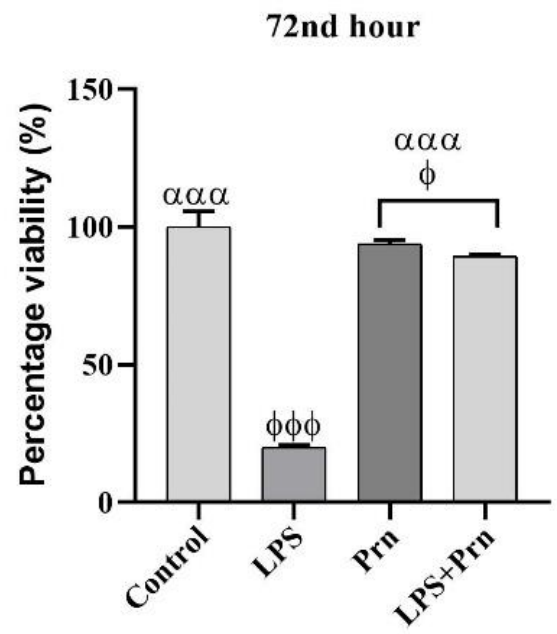

Figure 6. The effects of Prn and LPS on L929 cell line in 72nd hours. ( $\Phi$; according to control group, ${ }^{\Phi} \mathrm{p}<0.05,{ }^{\Phi \Phi} \mathrm{p}<0.01,{ }^{\Phi \Phi} \mathrm{p}<0.001 ; \alpha$ :according to LPS group ${ }^{\alpha} \mathrm{p}<0.05,{ }^{\alpha \alpha} \mathrm{p}<0.01,{ }^{\alpha \alpha \alpha} \mathrm{p}<0.001$ )

According to our results, Prn compound was determined to prevent cytotoxicity-related cell damage in the L929 cell line created with LPS. It was determined that L929 cells reduce cell damage caused by cytotoxicity caused by LPS depending on time. It was determined that the cell viability rate in the Prn + LPS group increased the cell proliferation at 24th hours $(\mathrm{p}$ $<0.01$ ), 48th hours ( $\mathrm{p}<0.001)$, and more 72nd hours ( $\mathrm{p}<0.001)$ and was statistically significant compared to the LPS group. When we look at our results as a whole, the cell viability rate in all periods (24th hour, 48th hour, and 72 nd hour) is above $85 \%$ and well 
above the 70\% rate recommended by ISO 10993-5: 2009 for cytotoxicity (DIN EN ISO, 2009) found to be.

\section{Discussion}

In this study, the effects of Prn compound isolated from the root of Ferulago pauciradiata on LPS-induced cytotoxicity cell injury model in L929 cell line were investigated. In this study, it was determined that Prn compound prevented cytotoxicity on L929 cell line at 24th hours, 48th hours and more 72nd hours, and increased cell proliferation and brought it closer to cell viability in the control group. When the results of our study were analyzed as a whole, results consistent with our hypothesis that the Prn compound reduced cytotoxicity cell damage was obtained.

One of the most common coumarin compounds found in the Apiaceae family, and especially in the genus Ferulago, is Prn. In studies conducted (Srikrishna et al., 2018; Hoang et al., 2017; Venugopala et al., 2013). Coumarins have been reported to have various pharmacological properties such as anti-inflammatory, antibacterial, antioxidant, antifugal, and anticoagulant. In accordance with the results of the studies conducted, while the effects of Prn, which is a coumarin derivative, on L929 cells at 24th, 48th and 72nd hours did not show any toxic effect compared to the control group, it was determined that Prn application increased the amount of decreased cell index in LPS groups.

As a result, studies (Mustafa et al., 2018; Kasumbwe et al., 2017) found that coumarins have a proliferative effect. When LPS was applied 1 hour after applying different doses of the Prn compound obtained from the root part of the $F$. pauciradiata, it was found that as the concentration of the Prn pure substance increased, the cell proliferation increased and the highest viable cell ratio was observed at a dose of $8 \mu \mathrm{g} / \mathrm{mL}$.

\section{Conclusion}

When we look at the results of our study as a whole, it was determined that the viability rates of the cells were above $85 \%$ as a result of the Prn application and it was significantly above the 70\% viable cell ratio recommended by ISO 10993-5: 2009 Din en ISO (2009), for cytotoxicity. These results showed us that Prn does not have a cytotoxic effect.

\section{Acknowledgments}

We would like to thank Prof. Dr. Hayrin DUMAN for all their time and effort in support for the identification of plant material.

\section{Competing interests}

The authors declare that they have no competing interests.

\section{Financial Disclosure}

This research did not receive any specific grant from funding agencies in the public, commercial, or not-for-profit sectors. 


\section{References}

DIN EN ISO 10993-5: Biologische Beurteilung von Medizinprodukten-Teil 5: Prüfungen auf In-vitro-Zytotoxizität (ISO 10993-5:2009); German Version of EN ISO 10993-5:2009; International Organisation for Standardization: Geneva, Switzerland, 2009.

Hoang A.T. Dong-Cheol K., Wonmin K. 2017. Anti-inflammatory coumarins from Paramignya trimera. Pharmaceutical Biology, 55(1), 1195-1201.

Hsiao, C.Y., Hung, C.Y., Tsai, T.H., Chak, K.F. 2012. 'A study of the wound healing mechanism of a traditional chinese medicine, Angelica sinensis, using a proteomic approach', Evidence-Based Complementary and Alternative Medicine. 1-15.

Kasumbwe K., Kabange N., Venugopala N. 2017. Synthetic Mono/di-halogenated Coumarin Derivatives and Their Anticancer Properties. Anti-Cancer Agents in Medicinal Chemistry, $17(2), 276-85$.

Karakaya S., Koca M., Simsek D. 2018. Antioxidant, Antimicrobial and Anticholinesterase Activities of Ferulago pauciradiata Boiss. \& Heldr. Growing in Turkey. Journal of Biologically Active Products from Nature, 8(6), 364-375.

Karakaya S., Özbek H., Güvenalp Z., Duman. 2017. Identification and Quantification of Coumarins in Four Ferulago Species (Apiaceae) Growing in Turkey by HPLC-DAD. J. Pharm. Sci. Exp. Pharmacol., 1, 35-42.

Kim, I.D., Ha, B.J. 2009. 'Paeoniflorin protects RAW 264.7 macrophages from LPS-induced cytotoxicity and genotoxicity’, Toxicology in Vitro, 23 (6), 1014-1019.

Kutlu, Z., Celik, M., Bilen, A., Halici, Z., Yıldırım, S., Karabulut, S., Karakaya, S., Delimustafaoglu, F., Aydin, P. 2020.' Effects of Umbelliferone isolated from the Ferulago pauciradiata Boiss. \& Heldr. Plant on Cecal Ligation and Puncture-Induced Sepsis Model in Rats', Biomedicine\&Pharmacotherapy, 127, 110206.

Millar N.L., Murrell G.A.C., McInnes I.B. Alarmins in tendinopathy: unravelling new mechanisms in a common disease. Rheumatology (Oxford). 2012;In Press.

Mustafa Y.F., Najem M.A., Tawffiq Z.S. 2018. Coumarins from Creston Apple Seeds: Isolation, Chemical Modification, and Cytotoxicity Study. Journal of Applied Pharmaceutical Science, 8(08), 49-56.

Sheba, L.A., Anuradha, V. 2019. 'An updated review on Couroupita guianensis Aubl: a sacred plant of India with myriad medicinal properties', Journal of Herbmed Pharmacology, 9(1):1-11.

Srikrishna D., Godugu C., Pramod K. 2018. A Review on Pharmacological Properties of Coumarins. Mini Reviews in Medicinal Chemistry, 18(2),113-141. 
Tokur, O., Aksoy, A. 2017. 'In Vitro Sitotoksisite Testleri', Harran Üniversitesi Veteriner Fakültesi Dergisi, 6 (1): 112-118.

Thomas W. Two types of fibroblast drive arthritis. 2019, Nature, 570,169-70.

Venugopala K.N., Rashmi V., Odhav B. 2013. Review on natural coumarin lead compounds for their pharmacological activity. BioMed Research International,14.

Zhang, S., Ma, J., Sheng, L., Zhang, D., Chen, X.,Ynag, J., Wang, D. 2017.' Total Coumarins from Hydrangea paniculata Show Renal Protective Effects in Lipopolysaccharide-Induced Acute Kidney Injury via Anti-inflammatory and Antioxidant Activities', Forintiers in Pharmacology, 8, 1-6. 